\title{
SISTEM PAKAR GINEKOLOGI DENGAN METODE FORWARD CHAINING DAN CERTAINTY FACTOR
}

\author{
Firna Yenila ${ }^{1)}$, Yogi Wiyandra ${ }^{2)}$ \\ ${ }^{1}$ Jurusan Sistem Informasi, Fakultas Ilmu Komputer, Universitas Putra Indonesia YPTK Padang \\ ${ }^{2}$ Jurusan Sistem Komputer, Fakultas Ilmu Komputer, Universitas Putra Indonesia YPTK Padang \\ Email: ${ }^{1}$ firnayenila@ upiyptk.ac.id, ${ }^{2}$ yogiwiyandra@ upiyptk.ac.id
}

\begin{abstract}
Gynecology is a female problem. Not infrequently among women doing various types of medical tests to determine the possibility they experienced when one obstacle occurred. And also among the women seemed to leave the condition alone due to various things including limited time to consult with experts, costs and various other types of obstacles. So given a solution in the form of an expert system that provides information like an expert. This system was built using a forward chaining and certainty factor method that coupled the forward chaining method with certainty factors with the aim of the two methods providing clear information by raising the percentage of the likelihood of users experiencing gynecological problems. This system aims to provide clear information to the user regarding gynecology suffered in the form of a percentage of confidence based on the expert.
\end{abstract}

Keywords: Ginekologi, Expert System, Forward Chaining, Certainty Factor

\section{Abstrak}

Ginekologi merupakan salah satu masalah kewanitaan. Tak jarang diantara para wanita melakukan berbagai jenis test medis untuk mengetahui kemungkinan yang dialaminya ketika salah satu kendala kewanitaan terjadi. Dan juga diantara para wanita terkesan membiarkan saja kondisi tersebut dikarenakan berbagai hal termasuk keterbatasan waktu untuk berkonsultasi dengan pakar, biaya dan berbagai jenis kendala lainnya. Sehingga diberikan sebuah solusi berupa sistem pakar yang memberikan informasi layaknya seorang pakar. Sistem ini dibangun dengan menggunakan metoda forward chaining dan certainty factor yang menggandengkan metoda forward chaining dengan certainty factor dengan tujuan dua metoda tersebut memberikan informasi yang jelas dengan memunculkan persentase kemungkinan user mengalami permasalahan ginekologi. Sistem ini bertujuan untuk memberikan informasi yang jelas kepada user mengenai ginekology yang diderita berupa persentase keyakinan berdasarkan pakar.

Keywords: Ginekologi, Sistem Pakar, Forward Chaining, Certainty Factor

\section{PENDAHULUAN}

Kesehatan wanita juga merupakan parameter kemampuan negara dalam menyelenggarakan pelayanan kesehatan terhadap masyarakat (Kementrian Kesehatan, 2016). Salah satu hal yang perlu diperhatikan untuk mencapai derajat kesehatan yang optimal adalah kesehatan wanita khususnya kesehatan reproduksi karena dampaknya luas dan menyangkut berbagai aspek kehidupan (Tjandrawinata, 2016).
Ginekologi adalah cabang kedokteran yang khusus mempelajari masalah kesehatan reproduksi wanita (vagina, rahim, ovarium, saluran telur), termasuk pengobatan dan perawatannya (Octaviana, 2017). Hal tersebut terjadi karena adanya beberapa faktor yang salah satunya kurangnya informasi mengenai kesehatan ginekologi disebabkan karena diantara mereka masih sulit untuk berkonsultasi (malu) secara langsung mengenai kesehatan pribadi atau vital. Dan ginekologi lebih dikenal dengan 
sekelompok penyakit yang berkembang di organ reproduksi wanita, seperti vulva, vagina, leher rahim, rahim, ovarium, dan tuba fallopi, yang semuanya terletak di dalam panggul (Selina, 2017). Penyakit ginekologi dinamai setelah organ yang merupakan sel-sel penyakit pada wanita terbentuk sesuai dengan kondisi-kondisi yang dialami, kondisi tersebut di jabarkan oleh para pakar sesuai dengan tabel 1 (Putri, 2017).

Sejauh ini banyak diantara masyarakat kurang memahami mengenai ginekologi yang kerap menyerang, sehingga resiko akhirnya menjadi fatal bagai mereka (Larasati, 2016).

Kejadian kasus ginekologi seperti halnya pada kasus penyakit kanker yang terjadi di Indonesia pada tahun 2013, sebanyak 25.012 menderita penyakit kanker serviks, dan di Jawa Timur sebanyak 9688 menderita penyakit kanker serviks. Untuk kasus mioma uteri ditemukan 2,39 - 11,7\% pada semua penderita ginekologi yang dirawat. Mioma uteri merupakan tumor pada pelvis yang paling sering dijumpai. Diperkirakan 1 dibanding 4 atau 5 wanita yang berumur lebih dari 35 tahun terdapat mioma uteri. Meskipun umumnya mioma tidak menunjukkan gejala, diperkirakan $60 \%$ dari laparotomi pelvis pada wanita dikerjakan dengan alasan mioma uteri. Pada kasus kanker serviks yang diketahui sejak dini memiliki kemungkinan untuk mendapatkan penanganan lebih baik (Yudianti, 2018)

Berdasarkan penelitian tersebut dapat di simpulkan bahwa kesehatan kesehatan wanita perlu diperhatikan untuk mengurangi kondisi tersebut.

Sejauh ini masyarakat kurang memiliki waktu yang sesuai untuk berkonsultasi dengan dokter bagian obstetri dan ginekologi sehingga lebih cendrung menahan diri atau membiarkan kondisi tersebut (Path, 2017). Sistem ini dibangun untuk membantu masyarakat dalam memberikan informasi mengenai ginekologi untuk orang awam sehingga mereka lebih memiliki informasi yang jelas mengenai kondisi tubuh. Apakah mengidap ginekologi atau normal seperti biasanya. Sistem ini merupakan sistem pakar yang menyadurkan kepakaran dari seorang dokter ahli obstetri dan ginekologi. Sistem ini dibangun dengan menggunakan metode certainty factor dengan tujuan memberikan informasi persentase kemungkinan user mengidap ginekologi tersebut atau tidak serta memberikan solusi awal untuk yang dikategorikan mengidap ginekologi.

\section{METODE PENELITIAN}

Berdasarkan permasalahan yang ada untuk menciptakan sebuah sistem pakar ginekologi dibutuhkan beberapa siklus atau kerangka penelitian sebagai berikut:

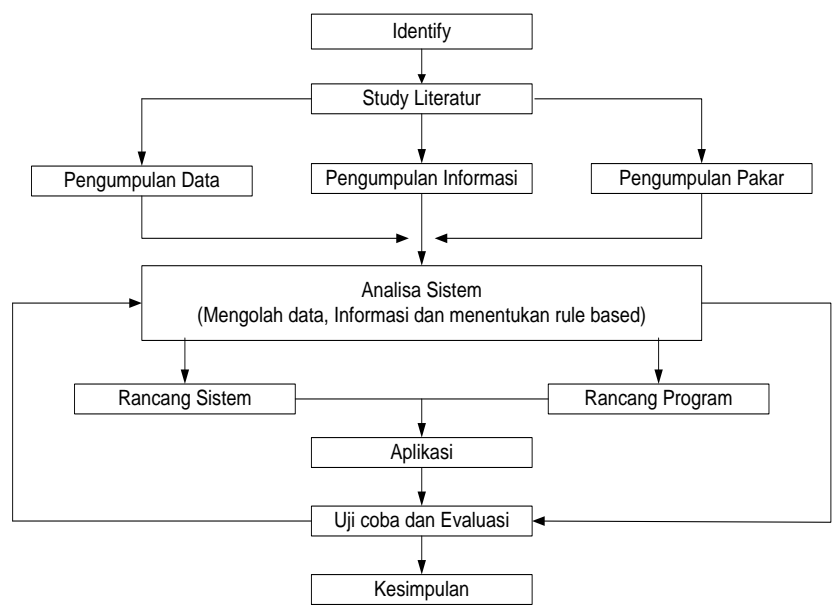

Gambar 1. Kerangka penelitian

Kerangka penelitian tersebut menjelaskan mengenai prosedur penelitian secara global hingga sistem bisa digunakan dengan maksimal. Penelitian ini menggunakan metode research dan development dengan mengembangkan informasi yang diberikan oleh pakar kedalam sebuah sistem yang berbasiskan knowledgebase dan memberikan output berupa aplikasi yang siap digunakan oleh user.

\section{SISTEM PAKAR}

\subsection{Sistem Pakar}

Sistem pakar merupakan sebuah kegiatan untuk memindahkan keahlian/kepakaran seseorang melalui sebuah sistem. Dan hal spesifik yang dimiliki oleh para ahli atau pakar dalam memecahkan masalah tertentu yang dituangkan dalam sebuah aplikasi (Yenila, 2019). Pengetahuan tentang sistem pakar dibentuk dari kaidah atau pengalaman tentang prilaku elemen dari domain bidang pengetahuan tertentu (Wiyandra, 2017). Pengetahuan pada sistem pakar diperoleh dari orang yang mempunyai pengetahuan pada suatu bidang (pakar bidang tertentu), buku- 
buku, jurnal ilmiah, majalah, maupun dokumentasi cetak lainnya. Sumber pengetahuan tersebut bisa dikenal dengan sumber keahlian (Nurajizah, 2018).

\subsection{Inference Engine}

Inference engine merupakan otak dari sistem pakar, bagian ini mengandung mekanisme fungsi berpikir dan pola-pola penalaran sistem yang digunakan oleh seorang pakar (Dou, 2014).

Mekanisme ini akan menganalisa suatu masalah tertentu dan kemudian mencari jawaban atau kesimpulan yang terbaik. Dari fakta-fakta yang diperoleh selama proses tanya-jawab dengan user, serta aturan-aturan yang tersimpan pada knowledge base, inference engine dapatmenar ik suatu kesimpulan dan memberikan rekomendasi atau saran yang diharapkan oleh user (Wicaknoso, 2018).

a. Forward Chaining

Forward chaining adalah salah satu metode dari sistem pakar yang mencari atau menelusuri solusi melalui masalah (Fahmi, 2018). Forward chaining (pelacakan ke depan) adalah pendekatan yang dimotori data ( data driven ) (Mahmudah, 2016). Dalam pendekatan ini pelacakan dimulai dari informasi masukan, dan mencoba menggambarkan kesimpulan. Pelacakan ke depan mencari fakta yang sesuai dengan bagian dari $I F$ dari aturan IF-THEN.

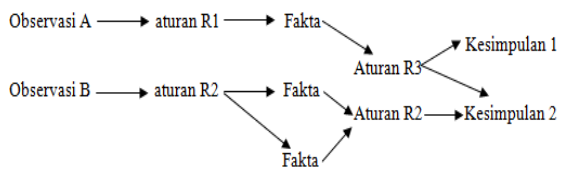

Gambar 2. Diagram Pelacakan

\section{b. Certainty Factor}

Metode certainty factor digunakan ketika menghadapi suatu masalah yang jawabannya tidak pasti. Ketidakpastian ini bisa merupakan probabilitas (Defkota, 2013).

Certainty factor menunjukkan ukuran kepastian terhadap suatu fakta atau aturan (Wiyandra, 2017). $\mathrm{CF}[\mathrm{h}, \mathrm{e}]=\mathrm{MB}[\mathrm{h}, \mathrm{e}]-\mathrm{MD}[\mathrm{h}, \mathrm{e}] \ldots(1)$ Keterangan :
$\mathrm{CF}[\mathrm{h}, \mathrm{e}]=$ Faktor kepastian

$\mathrm{MB}[\mathrm{h}, \mathrm{e}]=$ Measure of belief, ukuran kepercayaan atau tingkat keyakinan terhadap hipotesis (h), jika diberikan evidence (e) antara 0 dan 1

$\mathrm{MD}[\mathrm{h}, \mathrm{e}]=$ Measure of disbelief, ukuranketidakpercayaan atau tingkat keyakinan terhadap hipotesis (h), jika diberikan evidence (e) antara 0 dan 1. Adapun beberapa kombinasi certainty factor terhadap premis tertentu (Sari, 2017):

1. Certainty factor dengan satu premis

$$
\mathrm{CF}[\mathrm{h}, \mathrm{e}]=\mathrm{CF}[\mathrm{e}] * \mathrm{CF}[\text { rule }]=
$$

$\mathrm{CF}[$ user] $* \mathrm{CF}[$ pakar] ...(2)

2. Certainty factor dengan lebih dari satu premis

$$
\mathrm{CF}[\mathrm{A} \wedge \mathrm{B}]=
$$

$\operatorname{Min}(\mathrm{CF}[\mathrm{a}], \mathrm{CF}[\mathrm{b}]) \quad * \quad \mathrm{CF}[$ rule $]$ ...(3)

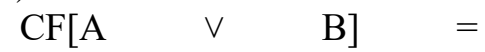
$\operatorname{Max}(\mathrm{CF}[\mathrm{a}], \mathrm{CF}[\mathrm{b}]) \quad * \quad \mathrm{CF}[$ rule $]$ ...(4)

3. Certainty factor dengan kesimpulan yang serupa $\mathrm{CF}$ gabungan $[\mathrm{CF} 1, \mathrm{CF} 2]=$ $\mathrm{CF} 1+\mathrm{CF} 2 *(1-\mathrm{CF} 1)$

Kelebihan dari metode ini adalah cocok digunakan pada sistem pakar yang mengukur sesuatu yang pasti atau tidak pasti seperti mendiagnosis penyakit dan perhitungan dari metode ini hanya berlaku untuk sekali hitung, serta hanya dapat mengolah dua data sehingga keakuratannya terjaga (Razandi, 2015).

\section{HASIL DAN PEMBAHASAN}

\subsection{Analisa}

Dalam analisis ini diberikan gambaran lebih jelas mengenai sistem pengenalan serta pertolongan pertama terhadap user yang memiliki permasalahan berhubungan dengan ginekology menurut beberapa orang pakar yang bergerak dibidang ginekology (gnikolog).

\begin{tabular}{c|l}
\multicolumn{2}{c}{ Tabel 1. Gejala Ginekologi } \\
\hline Kode & \multicolumn{1}{c}{ Gejala } \\
\hline G001 & $\begin{array}{l}\text { Siklus menstruasi yang tidak } \\
\text { teratur }\end{array}$ \\
\hline G002 & $\begin{array}{l}\text { Keputihan yang tidak normal } \\
\text { (Cair dan berdarah) }\end{array}$ \\
\hline G003 & Adanya nyeri di bagian panggul \\
\hline
\end{tabular}




\begin{tabular}{|c|c|}
\hline & atau di bagian punggung bawah \\
\hline G004 & $\begin{array}{l}\text { Badan menjadi lebih cepat lelah } \\
\text { dan lemas }\end{array}$ \\
\hline G005 & Nafsu makan menurun \\
\hline G006 & $\begin{array}{l}\text { Berat badan turun drastis padahal } \\
\text { tidak melakukan program diet }\end{array}$ \\
\hline G007 & $\begin{array}{l}\text { Salah satu bagian kaki menjadi } \\
\text { bengkak }\end{array}$ \\
\hline G008 & $\begin{array}{l}\text { Keluarnya cairan pada vagina } \\
\text { yang tidak normal dan disertai } \\
\text { bau menyengat }\end{array}$ \\
\hline G009 & $\begin{array}{l}\text { Pendarahan yang tak terduga } \\
\text { setelah menopause }\end{array}$ \\
\hline G010 & Perut selalu terasa kembung \\
\hline G011 & Pembengkakan pada perut \\
\hline G012 & Sakit saat berhubungan seksual. \\
\hline G013 & Mual \\
\hline G014 & Cepat kenyang \\
\hline G015 & $\begin{array}{l}\text { Perubahan pada kebiasaan buang } \\
\text { air besar, misalnya konstipasi } \\
\text { (sulit buang air besar) }\end{array}$ \\
\hline G016 & Nyeri tuba falopi \\
\hline G017 & Nyeri perut bagian bawah \\
\hline G018 & Tekanan kandung kemih \\
\hline G019 & $\begin{array}{l}\text { Benjolan atau pembengkakan di } \\
\text { daerah panggul }\end{array}$ \\
\hline G020 & Nyeri pada rongga panggul \\
\hline G021 & $\begin{array}{l}\text { Perdarahan dari vagina } \\
\text { (Perdarahan ini terjadi di antara } \\
\text { waktu menstruasi, setelah } \\
\text { berhubungan seksual, atau } \\
\text { setelah menopause) }\end{array}$ \\
\hline G022 & $\begin{array}{l}\text { Muncul rasa gatal atau terdapat } \\
\text { benjolan pada vagina. }\end{array}$ \\
\hline G023 & Cepat Kenyang \\
\hline G024 & $\begin{array}{l}\text { Sulit buang air kecil dan } \\
\text { sakit/nyeri }\end{array}$ \\
\hline G025 & Urine bercampur darah \\
\hline G026 & $\begin{array}{l}\text { Jumlah pasangan seks yang lebih } \\
\text { dari satu }\end{array}$ \\
\hline G027 & $\begin{array}{l}\text { Perubahan pada kondisi kulit, } \\
\text { seperti warna dan ketebalan kulit. } \\
\text { Kulit dapat berwarna merah, } \\
\text { putih, atau menggelap }\end{array}$ \\
\hline G028 & $\begin{array}{l}\text { Terdapat tahi lalat di area vulva } \\
\text { yang berubah bentuk atau warna. }\end{array}$ \\
\hline G029 & $\begin{array}{l}\text { Benjolan yang menyerupai } \\
\text { jerawat, bisul, atau luka terbuka. }\end{array}$ \\
\hline G030 & Pernah menggunakan DES \\
\hline G031 & Perokok \\
\hline G032 & Diabetes Meletus \\
\hline G033 & $\begin{array}{l}\text { Sering menggunakan cairan } \\
\text { douche }\end{array}$ \\
\hline G034 & Pernah aborsi/kurek \\
\hline G035 & Usia sex $<17$ Tahun \\
\hline
\end{tabular}

Sejauh ini jenis ginekology yang umum terjadi adalah sebagai berikut:
Tabel 2. Jenis Ginekologi

\begin{tabular}{c|l}
\hline Kode & \multicolumn{1}{c}{ Jenis Inseminasi } \\
\hline P1 & Kanker Serviks \\
\hline P2 & Endometrium \\
\hline P3 & Kanker tuba fallopi \\
\hline P4 & Kanker ovarium \\
\hline P5 & Kanker vulva \\
\hline
\end{tabular}

Berikut ini merupakan gejala ginekology berdasarkan pakar dan persentase hubungan penyakit dengan gejala menurut pakar.

Tabel 3. Gejala Ginekologi dan bobot

\begin{tabular}{|c|c|c|}
\hline Kode & Gejala & $\begin{array}{l}\text { Nilai } \\
\text { Bobot } \\
\text { Pakar }\end{array}$ \\
\hline G001 & $\begin{array}{l}\text { Siklus menstruasi yang } \\
\text { tidak teratur }\end{array}$ & 0.7 \\
\hline G002 & $\begin{array}{l}\text { Keputihan yang tidak } \\
\text { normal (Cair dan } \\
\text { berdarah) }\end{array}$ & 0.6 \\
\hline G003 & $\begin{array}{l}\text { Adanya nyeri di bagian } \\
\text { panggul atau di bagian } \\
\text { punggung bawah }\end{array}$ & 0.8 \\
\hline G004 & $\begin{array}{l}\text { Badan menjadi lebih } \\
\text { cepat lelah dan lemas }\end{array}$ & 0.3 \\
\hline G005 & Nafsu makan menurun & 0.3 \\
\hline G006 & $\begin{array}{l}\text { Berat badan turun drastis } \\
\text { padahal tidak melakukan } \\
\text { program diet }\end{array}$ & 0.6 \\
\hline G007 & $\begin{array}{l}\text { Salah satu bagian kaki } \\
\text { menjadi bengkak }\end{array}$ & 0.6 \\
\hline G008 & $\begin{array}{l}\text { Keluarnya cairan pada } \\
\text { vagina yang tidak normal } \\
\text { dan disertai bau } \\
\text { menyengat }\end{array}$ & 0.8 \\
\hline G009 & $\begin{array}{l}\text { Pendarahan yang tak } \\
\text { terduga setelah } \\
\text { menopause }\end{array}$ & 0.8 \\
\hline G010 & $\begin{array}{l}\text { Perut selalu terasa } \\
\text { kembung }\end{array}$ & 0.2 \\
\hline G011 & $\begin{array}{l}\text { Pembengkakan pada } \\
\text { perut }\end{array}$ & 0.4 \\
\hline G012 & $\begin{array}{l}\text { Sakit saat berhubungan } \\
\text { seksual. }\end{array}$ & 0.5 \\
\hline G013 & Mual & 0.2 \\
\hline G014 & Cepat kenyang & 0.2 \\
\hline G015 & $\begin{array}{l}\text { Perubahan pada } \\
\text { kebiasaan buang air } \\
\text { besar, misalnya } \\
\text { konstipasi (sulit buang air } \\
\text { besar) }\end{array}$ & 0.5 \\
\hline G016 & Nyeri tuba falopi & 0.8 \\
\hline G017 & Nyeri perut bagian bawah & 0.7 \\
\hline G018 & Tekanan kandung kemih & 0.7 \\
\hline G019 & Benjolan atau & 0.6 \\
\hline
\end{tabular}




\begin{tabular}{|c|c|c|}
\hline & $\begin{array}{l}\text { pembengkakan di daerah } \\
\text { panggul }\end{array}$ & \\
\hline G020 & $\begin{array}{l}\text { Nyeri pada rongga } \\
\text { panggul }\end{array}$ & 0.5 \\
\hline G021 & $\begin{array}{l}\text { Perdarahan dari vagina } \\
\text { (Perdarahan ini terjadi di } \\
\text { antara waktu menstruasi, } \\
\text { setelah berhubungan } \\
\text { seksual, atau } \\
\text { setelah menopause) }\end{array}$ & 0.8 \\
\hline G022 & $\begin{array}{l}\text { Muncul rasa gatal atau } \\
\text { terdapat benjolan pada } \\
\text { vagina. }\end{array}$ & 0.6 \\
\hline G023 & Cepat Kenyang & 0.2 \\
\hline G024 & $\begin{array}{l}\text { Sulit buang air kecil dan } \\
\text { sakit/nyeri }\end{array}$ & 0.4 \\
\hline G025 & Urine bercampur darah & 0.5 \\
\hline G026 & $\begin{array}{l}\text { Jumlah pasangan seks } \\
\text { yang lebih dari satu }\end{array}$ & 0.6 \\
\hline G027 & $\begin{array}{l}\text { Perubahan pada kondisi } \\
\text { kulit, seperti warna dan } \\
\text { ketebalan kulit. Kulit } \\
\text { dapat berwarna merah, } \\
\text { putih, atau menggelap }\end{array}$ & 0.4 \\
\hline G028 & $\begin{array}{l}\text { Terdapat tahi lalat di area } \\
\text { vulva yang berubah } \\
\text { bentuk atau warna. }\end{array}$ & 0.3 \\
\hline G029 & $\begin{array}{l}\text { Benjolan yang } \\
\text { menyerupai jerawat, } \\
\text { bisul, atau luka terbuka. }\end{array}$ & 0.5 \\
\hline G030 & $\begin{array}{l}\text { Pernah menggunakan } \\
\text { DES }\end{array}$ & 0.8 \\
\hline G031 & Perokok & 0.5 \\
\hline G032 & Diabetes Meletus & 0.8 \\
\hline G033 & $\begin{array}{l}\text { Sering menggunakan } \\
\text { cairan douche }\end{array}$ & 0.7 \\
\hline G034 & Pernah aborsi/kurek & 0.4 \\
\hline G035 & Usia sex $<17$ Tahun & 0.4 \\
\hline
\end{tabular}

Berikut ini merupakan tabel aturan/rule yang digunakan dalam penelitian yang mampu diterapkan dalam aplikasi.

Tabel 4. Tabel Rule

\begin{tabular}{c|l}
\hline No & \multicolumn{1}{|c}{ Rule } \\
\hline 1 & IF G001 AND G009 AND G013 \\
& AND G021 AND G025 AND G026 \\
& AND G031 AND G032 AND G033 \\
& AND G034 AND G035 THEN P1 \\
\hline 2 & IF G003 AND G009 AND G012 \\
& AND G020 AND G021 AND G024 \\
& AND G032 AND G035 THEN P2 \\
\hline Dst & \\
\hline
\end{tabular}

Persentase yang dihitung dalam desimal untuk mempertegas kesimpulan yang akan diberikan dalam penelitian.
Tabel 5. Bobot Certainty Factor

\begin{tabular}{l|l|c}
\hline No & \multicolumn{1}{|c|}{ Keterangan } & $\begin{array}{c}\text { Nilai } \\
\text { User }\end{array}$ \\
\hline 1 & Tidak & 0 \\
\hline 2 & Tidak Tahu & 0.2 \\
\hline 3 & Sedikit Yakin & 0.4 \\
\hline 4 & Cukup Yakin & 0.6 \\
\hline 5 & Yakin & 0.8 \\
\hline 6 & Sangat Yakin & 1 \\
\hline
\end{tabular}

Pembahasan diperlukan untuk mengetahui hasil dari penelitian hingga dapat menyelesaikan permasalaha. Permasalahan yang telah dirumuskan atau diteliti sebelumnya yaitu memastikan metoda hybdrid dapat digunakan untuk menarik kesimpulan pada kasus ini.

Langkah yang digunakan dengan menggunakan metode (Forward Chaining dan Certainty Factor) dalam memproses gejala-gejala berdasarkan diagnosakondisi awal atau penyakit menggunakan kaidah dengan premis/gejala tunggal. Formula dasar digunakan apabila belum ada nilai CF untuk setiap gejala yang memberikan diagnosa. Untuk mendapatkan nilai $\mathrm{CF}$ penguna dapat memilih dari 18 gejala yang ada dan member nilai bobot yang sesuai dengan gejala yang dialami oleh pengguna. Selanjutnya bobot nilai yang diberikan pengguna akan dikalikan dengan bobot nilai yang diberikan oleh pakar.

Contoh poses memperoleh nilai $\mathrm{CF}$ dengan menggunakan tabel rule, nilai bobot pengguna dan nilai bobot pakar:

Tabel 6. Tabel Rule (Aturan)

\begin{tabular}{c|l}
\hline No & \multicolumn{2}{|c}{ Rule } \\
\hline 1 & IF G001 AND G009 AND G013 AND \\
& G021 AND G025 AND G026 AND G031 \\
& AND G032 AND G033 AND G034 AND \\
& G035 THEN P1 \\
\hline Dst & \multicolumn{2}{l}{} \\
\hline
\end{tabular}

Setelah user berkonsultasi dan menghasilkan rule diatas dari aktifitas konsultasinya. User harus memberikan berapa persentase keyakinan mengalami kondisi tersebut. Tabel berikut merupakan simulasi awal terhadap bobot yang diberikan oleh user berdasarkan kondisi yang dialaminya.

Tabel 7. Nilai Bobot Pengguna

\begin{tabular}{c|c|c}
\hline Kode & Gejala & $\begin{array}{c}\text { Nilai } \\
\text { Bobot } \\
\text { Pengguna }\end{array}$ \\
\hline G001 & Siklus menstruasi & 0.8 \\
\hline
\end{tabular}




\begin{tabular}{c|l|c}
\hline & yang tidak teratur & \\
\hline G009 & $\begin{array}{l}\text { Pendarahan yang } \\
\text { tak terduga } \\
\text { setelah } \\
\text { menopause }\end{array}$ & 0.8 \\
\hline G013 & Mual & 0.5 \\
\hline G021 & $\begin{array}{l}\text { Perdarahan dari } \\
\text { vagina (Perdarahan } \\
\text { ini terjadi di antara } \\
\text { waktu menstruasi, } \\
\text { setelah } \\
\text { berhubungan } \\
\text { seksual, atau } \\
\text { setelah menopause) }\end{array}$ & 0.7 \\
\hline G025 & $\begin{array}{l}\text { Urine bercampur } \\
\text { darah }\end{array}$ & 0.7 \\
\hline G026 & $\begin{array}{l}\text { Jumlah pasangan } \\
\text { seks yang lebih } \\
\text { dari satu }\end{array}$ & 0.1 \\
\hline G031 & Perokok & 0.1 \\
\hline G032 & Diabetes Meletus & 0.8 \\
\hline G033 & $\begin{array}{l}\text { Sering } \\
\text { menggunakan } \\
\text { cairan douche }\end{array}$ & 0.7 \\
\hline G034 & $\begin{array}{l}\text { Pernah } \\
\text { aborsi/kurek }\end{array}$ & $\begin{array}{l}\text { Usia sex < 17 } \\
\text { Tahun }\end{array}$ \\
\hline G035 & 0.5 \\
\hline
\end{tabular}

Setelah bobot dari user didapatkan dilanjutkan dengan bobot pakar yang dirunut berdasarkan tabel 1 .

\section{Tabel 6. Nilai Bobot Pakar}

\begin{tabular}{c|l|c}
\hline Kode & \multicolumn{1}{|c}{ Gejala } & $\begin{array}{c}\text { Nilai } \\
\text { Bobot } \\
\text { Pengguna }\end{array}$ \\
\hline G001 & $\begin{array}{l}\text { Siklus menstruasi } \\
\text { yang tidak teratur }\end{array}$ & 0.7 \\
\hline G009 & $\begin{array}{l}\text { Pendarahan yang } \\
\text { tak terduga } \\
\text { setelah } \\
\text { menopause }\end{array}$ & 0.8 \\
\hline G013 & $\begin{array}{l}\text { Mual } \\
\text { G021 }\end{array}$ & $\begin{array}{l}\text { Perdarahan dari } \\
\text { vagina (Perdarahan } \\
\text { ini terjadi di antara } \\
\text { waktu menstruasi, } \\
\text { setelah } \\
\text { berhubungan } \\
\text { seksual, atau } \\
\text { setelah menopause) }\end{array}$ \\
\hline G025 & $\begin{array}{l}\text { Urine bercampur } \\
\text { darah }\end{array}$ & 0.2 \\
\hline \multicolumn{2}{|l}{} \\
\hline
\end{tabular}

\begin{tabular}{c|l|c}
\hline G026 & $\begin{array}{l}\text { Jumlah pasangan } \\
\text { seks yang lebih } \\
\text { dari satu }\end{array}$ & 0.6 \\
\hline G031 & Perokok & 0.5 \\
\hline G032 & Diabetes Meletus & 0.8 \\
\hline G033 & $\begin{array}{l}\text { Sering } \\
\text { menggunakan } \\
\text { cairan douche }\end{array}$ & 0.7 \\
\hline G034 & $\begin{array}{l}\text { Pernah } \\
\text { aborsi/kurek }\end{array}$ & 0.4 \\
\hline G035 & $\begin{array}{l}\text { Usia sex }<17 \\
\text { Tahun }\end{array}$ & 0.4 \\
\hline
\end{tabular}

$\begin{aligned} \text { Cfgejala1 }= & \mathrm{CF}(\text { user })^{*} \mathrm{CF}(\text { pakar }) \\ & 0.8^{*} 0.7 \\ \text { Cfgejala2 }= & 0.56 \\ & \mathrm{CF}(\text { user }) * \mathrm{CF} \text { (pakar) } \\ & 0.8^{*} 0.8 \\ & 0.64\end{aligned}$

Cfgejala3 $=\mathrm{CF}($ user $) * \mathrm{CF}($ pakar $)$ $0.5 * 0.2$

0.10

Cfgejala4 $=\mathrm{CF}($ user $) * \mathrm{CF}$ (pakar) $0.7 * 0.8$

0.56

Cfgejala5 $=\mathrm{CF}(\text { user })^{*} \mathrm{CF}$ (pakar)

$0.7 * 0.5$

0.35
Cfgejala6 $=\mathrm{CF}($ user $) * \mathrm{CF}$ (pakar) $0.6 * 0.1$
0.06

Cfgejala7 $=\mathrm{CF}($ user $) * \mathrm{CF}$ (pakar) $0.1 * 0.5$ 0.05

Cfgejala8 $=\mathrm{CF}($ user $) * \mathrm{CF}($ pakar $)$ $0.8 * 0.8$ 0.56

Cfgejala9 $=\mathrm{CF}$ (user) $* \mathrm{CF}$ (pakar) $0.7 * 0.7$

0.49

$$
\begin{aligned}
\text { Cfgejala10 }= & \mathrm{CF}(\text { user }) * \mathrm{CF}(\text { pakar }) \\
& 0.7^{*} 0.4 \\
& 0.05 \\
\text { Cfgejala11 = } & \mathrm{CF}(\text { user }) * \mathrm{CF}(\text { pakar }) \\
& 0.5^{*} 0.4 \\
& 0.20
\end{aligned}
$$

Dikarenakan terdapat lebih dari satu gejala, maka untuk menentukan CF selanjutnya digunakan persamaan berikut :

CFcombine1(CFgejala1, CFgejala2) = CFgejala1+CFgejala2*(1- CFgejala $=0.56+0.64 *(1-0.56)$ CFold 1 $=0.8416$ 
CFcombine2(CFold1, CFgejala3) =

CFold $1+$ CFgejala $3 *(1-$ CFold 1$)$

$=0.8416+0.1 *(1-0.8416)$ CFold 2

$=0.85744$

Certainty factor kombinasi bisa dilakukan sampai pada gejala ke 11 hingga dimunculkan nilai, dari nilai tersebut maka dilakukan aktifitas persentase sebagai contoh sebagai berikut:

Persentase $=$ CFpenyakit $* 100$

$=0.85744 * 100$

$=85.744 \%$

Berdasarkan hasil perhitungan, maka keterangan tingkat keyakinan berdasarkan tabel interpretasi dari pakar dan persentase akhir adalah YAKIN. Dikarenakan terdapat lebih dari satu gejala, maka untuk menentukan $\mathrm{CF}$ selanjutnya digunakan persamaan berikut :

CFcombine1(CFgejala1, CFgejala2) =

CFgejala1 $+\quad$ CFgejala2*(1- CFgejala1 $)=$ $0.56+0.64 *(1-0.56)$ CFold 1

\section{$=0.8416$}

CFcombine2(CFold1, CFgejala3) =

CFold1+ CFgejala $3 *(1-$ CFold 1$)$

$=0.8416+0.1 *(1-0.8416)$ CFold 2

$=0.85744$

Certainty factor kombinasi bisa dilakukan sampai pada gejala ke 11 hingga dimunculkan nilai, dari nilai tersebut maka dilakukan aktifitas persentase sebagai contoh sebagai berikut:

Persentase $=$ CFpenyakit $* 100$

$=0.85744 * 100$

$=85.744 \%$

Berdasarkan hasil perhitungan, maka keterangan tingkat keyakinan berdasarkan tabel interpretasi dari pakar dan persentase akhir adalah YAKIN.

\subsection{Hasil}

Berdasarkan analisa terhadap ginekologi diatas dapat dihasilkan sebuah sistem sebagai berikut:

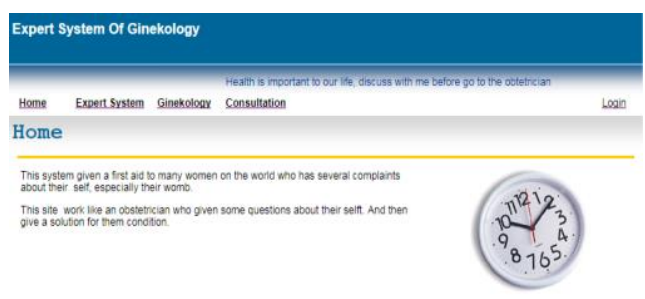

Gambar 3. Tampilan awal

Setelah user mengakses tampilan awal tersebut, user akan diarahkan kepada aktivitas konsultasi untuk melakukan penggunaan sistem pakar. User akan diminta untuk menjawab setiap pertanyaan yang diajukan oleh sistem sesuai dengan kondisi user pada saat itu:

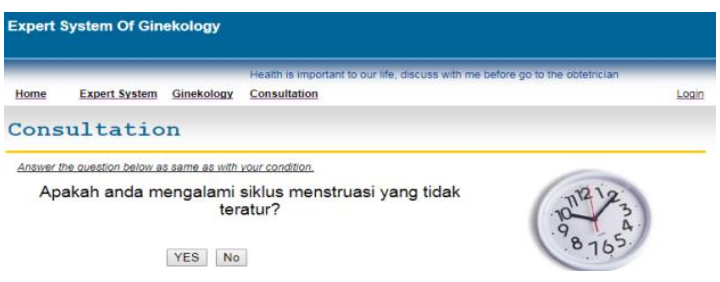

Gambar 4. Konsultasi

Apabila user menjawab "ya" dari pertanyaan tersebut maka sistem akan meminta user memberikan persentase yang dibutuhkan untuk mempertegas kemungkinan user mengalami kondisi tersebut hingga kemudian konklusi didapatkan. Dan jika user menjawab "tidak" maka sistem akan menuju ke pertanyaan selanjutnya.

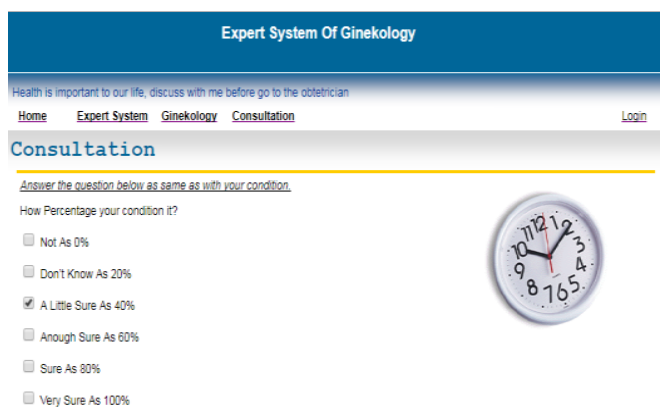

Gambar 5. Persentase Kepastian

Apabila konsultasi selesai makan sistem akan memberikan keputusan atau kesimpulan berupa sebuah informasi yang bisa dimiliki oleh user dalam bentuk softcopy ataupun hardcopy.

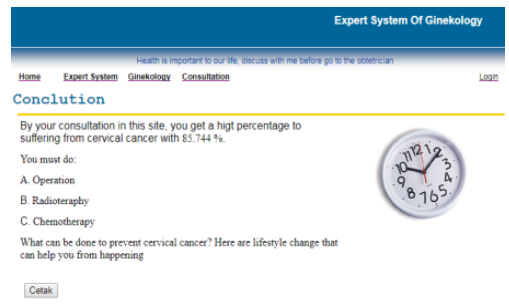

Gambar 6. Konklusi

\section{KESIMPULAN}

Berdasarkan pembahasan sebelumnya, dapat diambil kesimpulan dari penelitian dan pembuatan sistem pakar ginekology. Dalam upaya membantu wanita untuk menjaga kesehatan kewanitaannya dari dini sehingga terhindar dari masalah ginekology tersebut, 
aplikasi sistem pakar ini dapat menjadi alternatif pemecahan masalah, diantaranya;

a. Sistem pakar dibuat agar membantu wanitauntuk mendapatkan informasi tentang ginekology dan tidak diharuskan untuk berkonsultasi langsung dengan para pakar.

b. Metode (Forward Chaining dan Certanty Factor) dapat memberikan diagnosa ginekology berdasarkan gejalagejala yang diberikan berdasarkan hasil perhitungan, maka keterangan tingkat keyakinan berdasarkan tabel interpretasi dari pakar dan persentase akhir sebesar $85.744 \%$ adalah yakin kedua metode ini diterapkan ntuk menyelesaikan masalah yang ada.

\section{DAFTAR PUSTAKA}

Larasati, T. A., \& Alatas, F. (2016). Dismenore primer dan faktor risiko Dismenore primer pada Remaja. Jurnal Majority, 5(3), 79-84.

Kementrian Kesehatan, R. I. (2016). Pedoman Pencegahan dan Penangulangan Anemia Pada Remaja Putri dan Wanita Usia Subur (WUS). Direktorat Gii Mayarakat, Kemenkes RI.

Mahmudah, M., Yaunin, Y., \& Lestari, Y. (2016). Faktor-faktor yang berhubungan dengan perilaku seksual remaja di Kota Padang. Jurnal Kesehatan Andalas, 5(2).

Sari, Y. P., Mulyanti, L. D., \& Oktriani, T. (2017). Pengaruh Pendidikan Kesehatan Reproduksi Menggunakan Metode Mentoring Terhadap Pengetahuan Remaja Tentang Kesehatan Reproduksi. NERS Jurnal Keperawatan, 11(1), 41-49.

Octaviana, A., \& Pranajaya, R. (2017). Usia dan Paritas dengan Kejadian Mioma Uteri. Jurnal Ilmiah Keperawatan Sai Betik, 10(2), 209-214.

Selina, P. (2017). Hubungan antara usia ibu dan paritas dengan kejadian perdarahan postpartum di Rumah Sakit" $X^{\prime \prime}$ Surabaya (Doctoral dissertation, Widya Mandala Catholic University Surabaya).

Putri, R. H. (2017). Kualitas hidup pasien kanker ginekologi yang menjalani terapi. Jurnal Aisyah: Jurnal Ilmu Kesehatan, 2(1), 69-74.

Paat, C., Kristanto, E., \& Kalalo, F. P. (2017). Analisis Pelaksanaan Clinical Pathway di
RSUP Prof. Dr. RD Kandou Manado. Community Health, 2(2).

Yenila, F., \& Wiyandra, Y. (2019). Expert System Eating Disorder To Youth With The Hybrid Method. SinkrOn, 4(1), 149154.

Wiyandra, Y., Yenila, F., \& Marfalino, H. (2019). Sistem Pakar Progeria Di Indonesia Dengan Menggunakan Metoda Certainty Factor. EXPLORE, 9(1), 47-53.

Nurajizah, S., \& Saputra, M. (2018). Sistem Pakar Berbasis Android Untuk Diagnosa Penyakit Kulit Kucing Dengan Metode Forward Chaining. Jurnal Pilar Nusa Mandiri, 14(1), 7-14.

Wicaksono, N. A. (2018). SISTEM PAKAR UNTUK IDENTIFIKASI PENENTUAN STATUS KESUBURAN HEWAN TERNAK SAPI BETINA DENGAN METODE DEMPSTER SHAFER THEORY (Doctoral dissertation, Universitas Gadjah Mada).

Razandi, Y., Pourghasemi, H. R., Neisani, N. S., \& Rahmati, O. (2015). Application of analytical hierarchy process, frequency ratio, and certainty factor models for groundwater potential mapping using GIS. Earth Science Informatics, 8(4), 867883.

Dou, J., Oguchi, T., Hayakawa, Y. S., Uchiyama, S., Saito, H., \& Paudel, U. (2014). GIS-based landslide susceptibility mapping using a certainty factor model and its validation in the Chuetsu Area, Central Japan. In Landslide science for a safer geoenvironment (pp. 419-424). Springer, Cham.

Yudianti, I., \& Nurhayati, R. (2018). HEALTH BELIEF MODEL (HBM) DAN KETERLAMBATAN RUJUKAN KASUS GINEKOLOGI. MIKIA: Mimbar Ilmiah Kesehatan Ibu dan Anak (Maternal and Neonatal Health Journal), 2(1).

Tjandrawinata, R. R. (2016). Industri 4.0: Revolusi industri abad ini dan pengaruhnya pada bidang kesehatan dan bioteknologi. Jurnal Medicinus, 29(1). 